\title{
Implications of Method Chosen for Analysis of Fatty Acids in Meat: A Review
}

\author{
${ }^{1}$ Livia Facuri Araujo Macedo, ${ }^{1}$ Ellen Cristina Quirino Lacerda, \\ ${ }^{1}$ Roberio Rodrigues Silva, ${ }^{1}$ Julliana Izabelle Simionato, ${ }^{2}$ Mayka Reghiany Pedrao, \\ ${ }^{2}$ Fabio Augusto Garcia Coro and ${ }^{2}$ Nilson Evelazio de Souza \\ ${ }^{1}$ Department of Basic Studies and Instrumental, \\ State University Southwest of Bahia, Praça Primavera, 40, Itapetinga, 45700-000, Brazil \\ ${ }^{2}$ Departtment of Food Technology, University of Paraná, \\ Rua dos Pioneiros, 3131, Londrina, 860356-370, Paraná, Brazil
}

Received 2012-05-14, Revised 2012-06-15; Accepted 2012-07-06

\begin{abstract}
The influence of the beef Fatty Acid (FA) profile on human health, has become a recurring concern. For an analysis of the lipid composition of food, it is necessary that the complex lipids be quantified in a suitable form for subsequent analysis of their composition by gas chromatography. The choice of appropriate methods of lipid extraction and esterification of fatty acids, is important in preventing chemical changes from within occurring in these molecules and the forming of artifacts. Among the methods used for quantification of lipids, those that use a mixture of polar and nonpolar solvents separate the lipids in the sample of the non-lipid components. As these methods were carried at ambient temperature, they most suitable for further analysis of the FA profile. These methods were extracted lipids efficiently and did not alter their chemical constitution. The methods of derivation of fatty acids for esterification could be catalyzed by acids or bases. The method was chosen to convert the lipids in Fatty Acid Methyl Esters (FAME) and allow their analysis by gas chromatography, should not lead to incomplete conversion of lipids into their FAME or form artifacts. The reagents commonly used in the transesterification of triacylglycerols in meat samples were the hydroxides of sodium or potassium hydroxide in methanol. Transesterification with these reagents could be developed at room temperature in a short period of time. It becomes a reliable technique for the identification of isomers of fatty acids such as conjugated linoleic acid. No single method performs optimally in all situations. The researcher must know the nature of the sample and select the appropriate method.
\end{abstract}

Keywords: Fatty Acid Methyl Esters (FAME), Fatty Acid (FA), Solvents Separate, Conjugated Linoleic, Extract Lipids, Gas Chromatography, Reagents Commonly, Transesterification of Triacylglycerols

\section{INTRODUCTION}

The search for a healthier diet has led consumers to worry about the amount of fats in foods, since their intake is associated with excess risk of cardiovascular disease, obesity and cancer (Whetsell et al., 2003, Prado et al., 2008a). Fats containing saturated fatty acids can raise LDL levels in the blood. However, the fatty acids with higher hypercholesterolemic effects are lauric (12:0), myristic (14:0) and palmitic acid (16:0) (Grummer, 1991; Bragagnolo, 2001). Among them, the most atherogenic (lauric and myristic) are underrepresented in beef (less than $1 \%$ and 3 , respectively) (Whetsell et al., 2003). Since palmitic acid
(16:0), despite representing $27 \%$ of lipids (Whetsell et al., 2003), is considered to have the lowest hypercholesterolemic effects. Thus, knowledge of the fatty acid profile of beef and its effect on human health, has become a recurring theme (Oliveira et al., 2009).

The extraction and quantitation of lipids may require several steps which include: (1) Pretreatment, including drying, reducing particle size and possibly acid hydrolysis in order to release the lipid, (2) Homogenization of the tissue in the presence of solvent/system solvent, (3) the separation of liquids from the solids (4) Removal of non-lipid contaminants, (5) Removal of the solvents and drying (6) Calculations of 
the amounts of lipids by weight difference (Sahidi, 2001). Since the process of analysis of Fatty Acid Methyl Esters (FAME) is the esterification of lipids, injection, separation, identification and quantification of FAME. All these steps must be optimized and carried out meticulously so as to achieve the necessary accuracy and precision of the analysis (Eder, 1995), several studies are currently being conducted in this direction (Cheng et al., 2011; Tanamati et al., 2005; Manirakiza et al., 2001).

Advances in chromatographic liquid and gas influenced the study of fatty acids, contributing, among other things, with the detailed investigation of some positional and geometric isomers, with distinct biological functions, which hitherto could not be separated or identified (Simionato et al., 2010).

To Hammond (2001) cited by Palmiquist and Jenkins (2003), "Gas chromatography was probably the main and largest event of the 20th century for analytical science.

For analysis of the lipid composition of food it is necessary that the complex lipids be pretreated. Thus making the individual fatty acids available for chromatographic analysis. Therefore, the fatty acids from lipid complexes must be converted into their corresponding methyl esters, turning them volatile and thus facilitating the GC analysis. Various methods of derivatization may be employed for the esterification of fatty acids (Eder, 1995, Li and Watkins 2001, Millinsk et al., 2008; 2011).

Based on these, the aim of this review is to bring an approach to choosing the appropriate method for analysis of fatty acids by gas chromatography in meat, in order to maintain integrity and ensure that the analysis be as real as possible.

\subsection{Lipid Extraction}

The lipids in the tissues occur in a variety of physical forms. In beef, about $90 \%$ of the lipids are in the form of triacylglycerols, which are composed of a glycerol molecule and three fatty acids.

During the process of extracting lipids, there must be disruption of interactions such as van der Waals forces and covalent bonds, which act to form complexes between lipids and proteins or carbohydrates (Christie, 1991; Sahidi, 2001). Thus, for the determination of total fat, which requires a quantitative extraction of all classes of lipid compounds, solvents or various combinations of solvents are suggested as extractors (Christie, 2011; Aued-Pimentel et al., 2010; Sahidi, 2001). In most analysis of lipids, non-polar solvents, such as chloroform, are used to break hydrophobic interactions (lipids with hydrophobic chains-triacylglycerols) as polar solvents with high dielectric constant, such as methanol, break hydrogen bonds (phospholipids and glycolipids) (Aued-Pimentel et al., 2010).

According Aued-Pimentel et al. (2010), several gravimetric methods of lipid analysis, are available. The choice of the extraction depends on the nature of the tissue matrix, e.g., if the sample is of animal, vegetable or microbial origin (Christie, 1991). Each method applies to different products according to their characteristics such as moisture levels, use of additives and processing technology, which could influence the performance of each method (Aued-Pimentel et al., 2010). Moreover, the AG values of total fat obtained through the different gravimetric methods have great influence on the values of these fatty acids as the total fat content is employed for quantifying fatty acids (Alerstam and Christie, 1993; Aued-Pimentel et al., 2010). Thus, the methods used to store the samples as well as to extract lipids must be carefully chosen so that the integrity of the lipids is maintained (Christie, 1991).

The extraction of fat based on the Soxhlet method (AOAC, 1995) typically uses hexane, diethyl ether or petroleum ether at discontinuous and intermittent refluxes of the hot solvent (Aued-Pimentel et al., 2010; Sahidi, 2001). The method is performed without direct contact with the sample. Removal occurs mainly on nonpolar lipids present in the samples with high or low fat. On the other hand, methods using chloroformmethanol, 2:1 v/v, as suggested by Folch et al. (1957) and Bligh and Dyer (1959), have been extensively used to quantify the total lipids from biological samples (animal tissues, plants and bacteria) (Alerstam and Christie, 1993; Sahidi, 2001; Aued-Pimentel et al., 2010) and extract both polar and nonpolar lipids (Sahidi, 2001). Endogenous water in the tissue is a ternary component of the system (Christie, 1991; 2011). Tanamati et al. (2005) conducted a comparative study of nine extraction methods used for determination of lipids in meat samples. Noting that the extraction methods described by Folch et al. (1957) and Bligh and Dyer (1959) have a higher efficiency compared to other techniques which do not use organic solvents and the method of Bligh and Dyer, unmodified and modified, which showed a better performance with regard to lipid extraction of samples meat.

Thus, it is noted that methods that use cold solvent mixtures such as those proposed by Folch et al. (1957) and Bligh and Dyer (1959), have several advantages. Among these are the extraction of all lipid classes (polar and nonpolar) and the fact that they can be used in dried samples and/or humid conditions, preserving the integrity of lipids because it does not use heat and it is a simple method, although it uses significant amounts of organic solvents and manipulation of large sample. 
In the method developed by Folch et al. (1957), the extract is mixed and balanced with a quarter of its volume with saline (Christie, 1991). After stirring, the solvents separate into two layers or phases. The backsheet is equivalent to $60 \%$ of the total volume and consists of chloroform-methanol-water in ratios of 86:14:1 containing almost all of the lipids. The upper phase consists of the same solvents in proportions of $3: 48: 47$, respectively and contains many of the non-lipid contaminants (Christie, 1991; 2011). The lipids in the chloroform layer are isolated using a separatory funnel (Sahidi, 2001). It is not always known how important the proportions of chloroform, methanol and water phases are combined, but they should approach 8:4:3, otherwise selective loss of lipids may occur (Christie, 1991). According Christie (2011), developed according to the proper protocols, this method can provide reliable results.

The lipid extraction method of Bligh and Dyer (1959) has been suggested to extract fatty acids with low molecular weight. However, extraction efficiency is strongly influenced by the experimental variables such as the ratio of chloroform, methanol and water in the proportion of $1: 2: 0.8$ and $2: 2: 1.8$ and, in the initial and final steps of the extraction, respectively (AuedPimentel et al., 2010).

The method described by Bligh and Dyer (1959) is a simple adaptation of the method of Folch et al. (1957) and was developed as an economical way (in terms of solvents and volumes) to extract the lipids in tissues with relatively few lipids (unsaturated fatty acids rarely exceed $1 \%$ of fresh weight) and high proportion of water (Alerstam and Christie, 1993). This method has been shown to extract the fat from milk and dairy products, as well as muscle to extract lipids (AuedPimentel et al., 2010; Sahidi, 2001). His condition extraction means, prevents the loss of low molecular weight molecules (Aued-Pimentel et al., 2010).

The aforementioned methods are recommended for the determination of the lipid samples for the determination of fatty acids and other characterization. According Aued-Pimentel et al. (2010), their environment and condition of extracting ability of the solvent mixture, to extract lipids from different classes do not change the structure of these molecules.

According to official AOAC methods, the basic hydrolysis used in samples of milk and cheese (AOAC 933.05 989.05/AOAC) and acid hydrolysis (AOAC 963.15) are employed to solubilize the casein digest and other compounds to release the fat prior to extraction. However, acid hydrolysis provides a greater amount of fat to cheese milk samples and is not likely to extract lipid material such as glycerol and low molecular weight carbohydrate (Aued-Pimentel et al., 2010).
Thus, it is observed that the choice of the method used in the study of lipid extraction and quantification of fatty acids depends on many variables defined in each procedure, such as solvent extraction, pretreatment characteristics of the samples (fat and humidity) and quantification of the AG normalization or internal standards.

In recent years, several studies aiming to evaluate the effects of feed (Fugita et al., 2012; Zawadzki et al., 2011; Valero et al., 2011; Sun et al., 2009; Fernandes et al., 2009; Jorge et al., 2009; Kazama et al., 2008; Silva et al., 2002; Prado et al., 2008b), genetic groups (Ito et al., 2012; Maggione et al., 2009; Rossato et al., 2009; Ducatti et al., 2009; Oliveira et al., 2009; Orellana et al., 2009; Abrahão et al., 2008; Prado et al., 2008a; 2008c; 2008d), sex (Prado et al., 2009a; 2009b; Aricetti et al., 2008, Kuss et al., 2006), slaughter age (Ito et al., 2010), effect of a Luteinizing Hormone-Releasing Hormone (LHRH) fusion protein vaccine vs. surgical castration (Ruiz et al., 2005) and the anatomical location of muscles (Macedo et al., 2008) on meat quality in cattle, quantified the total fat, using gravimetric methods. It has been observed that, in general, if the objective is, beyond the quantification of total lipids, the quantification of fatty acids of meat lipids, mainly of polyunsaturated lipids, the methods used by researchers involve extracting lipids and sampling the "fresh" ones with solvents at room temperature. The method described by Bligh and Dyer (1959) has been the most widely used to extract all classes of lipids maintaining their integrity, using small volumes of reagents in order to make it simple to implement.

However, Orellana et al. (2009) chose to measure the percentage of fat from the meat using the Soxhlet method (ISO R-1443), while an adaptation of the method described by Folch et al. (1957), was used for the extraction of intramuscular lipids of beef. Since the determination of levels of total fat has an influence on the determination of fatty acids from the sample (Aued-Pimentel et al., 2010), despite the increased reagent use, handling and greater time spent in the analysis, the use of two gravimetric methods, such as the Soxhlet and Folch et al. (1957), could bring greater accuracy to the results.

Although recommended for extracting lipids from samples with high water content and low in fat, Maggione et al. (2009) and Kuss et al. (2006), used the method of Folch et al. (1957) with modifications, to extract lipids from beef samples submitted to pre-drying in a forced air oven at $55^{\circ} \mathrm{C}$. After the separation of the solvents, the organic layer containing chloroform was subjected to a water bath at $40^{\circ} \mathrm{C}$, under a flow of compressed air, in both cases. According to Christie (1991), it is difficult to extract dehydrated lipids tissue and it may be necessary to rehydrate them in compliance with the volumes of chloroform, methanol and water in proportions of 8:4:3. However, possible changes in lipid 
composition, caused by dehydration of the sample would be irreversible. Still according to Christie (1991), tissue homogenates, is generally not necessary to warm the solvents used in the method of Folch et al. (1957).

In general, for the analysis of lipids, extraction of the tissues must be performed by avoiding changes in its constitution or with the formation of artifacts (Sahidi, 2001). Thus, it is observed that there may be changes in the methodology of extracting lipids from beef. However, lipid extraction methods described by Folch et al. (1957) and Bligh and Dyer (1959), are the most widely used procedures (Alerstam and Christie, 1993).

\subsection{Preparation of Fatty Acid Methyl Esters (FAME)}

The traditional analysis of fatty acids involves lipid derivatives to form more volatile and less polar compounds (Fuentes et al., 2006).

A method for preparing methyl esters of fatty acids for analysis by gas chromatography should preferably be simple, fast and quantitative and should not give rise to changes or structures and unwanted side reactions (Morrison and Schmidt, 1964).

The process of deriving the fatty acid analysis can be performed by acidic or basic catalysis (Eder, 1995; Millinsk et al., 2008; Simionato et al., 2010; Ichihara and Fukubayashi 2010; Millinsk et al., 2011). The methylation catalyzed by acid is commonly used because it is effective under many conditions and methyls all fatty acids, including the esterified and unesterified and those in salt form. Now, the only alkaline methylation transesterify fatty acids that are in the form of glyceride (triacylglycerols) (Palmiquist and Jenkins, 2003).

However, the esterification of fatty acids for analysis by gas chromatography can cause some problems such as incomplete conversion of lipids into Fatty Acid Methyl Esters (FAME), changes in its composition during the transesterification, formation of artifacts that can be mistakenly identified as fatty acids or the overlapping with the peaks of the methyl esters of gas chromatography analysis and contamination resulting in damage to column chromatography due to traces of reagents esterification of FAME, incomplete extraction and loss of many of the short-chain FAME volatiles (Eder, 1995; Millinsk et al., 2008 ; 2011). Making it necessary to seek methods to minimize such interference in the chromatographic analysis (Simionato et al., 2010).

In accordance with $\mathrm{Li}$ and Watkins (2001), the procedure adopted by AOCS, 1989 and (Stark and Firestone, 1996), in the preparation of FAME, occurs if the small sample from lipids $(2-50 \mathrm{mg})$, by saponification with sodium hydroxide, is followed by esterification catalyzed by boron trifluoride $\left(\mathrm{BF}_{3}\right)$. This protocol fits most analysis of lipids. However, since the $\mathrm{BF}_{3}$ catalyst and other acids such as $\mathrm{HCl}$ or $\mathrm{H}_{2} \mathrm{SO}_{4}$, change the conformation of conjugated dienoic fatty acids Conjugated Linoleic Acid (CLA) and favors the formation of artifacts which may make it difficult for chromatographic analysis (Fuentes et al., 2006), this method is not recommended for samples of lipids that have these special structures, such as milk and dairy products and meat from ruminants.

The reagents commonly used in the transesterification of triacylglycerols by basic catalysis is sodium hydroxide $(\mathrm{NaOH})$ or potassium $(\mathrm{KOH})$ in methanol (Millinsk et al., 2008; Ichihara and Fukubayashi, 2010) and sodium methoxide $\left(\mathrm{NaOCH}_{3}\right)$ in methanol (Millinsk et al., 2008). Transesterification with these reagents can be developed at room temperature in a short period of time. On the other hand, a disadvantage is that they do not convert free fatty acids in FAME, which limit its application to oils with high acidity (Simionato et al., 2010; Ichihara and Fukubayashi, 2010).

The incomplete conversion of lipids in FAME alters the composition of fatty acids during esterification and formation of compounds that can be identified, wrongly, as fatty acids, may also affect the quantification of FAME directly (Millinsk et al., 2008).

Furthermore, according to Millinsk et al. (2008), the method described in ISO 5508, which uses cheaper and less toxic reagents such as sodium hydroxide, can be used on samples with low acidity, since the possible formation of salts, due to the presence of free fatty acids is minimized.

As research on Conjugated Linoleic Acid (CLA) and other fatty acid conjugates, have become more popular, it is essential not to leave missing information on the analysis of its composition, due to improper application protocol methylation ( $\mathrm{Li}$ and Watkins, 2001). The CLA isomers, occur naturally in food derived from ruminants (Sun et al., 2009) being produced as intermediates of the biohydrogenation of polyunsaturated fatty acids, specifically linolenic (C18: 2 cis-9, cis-12) and $\alpha-$ linolenic acid (C18: 3 cis-9, cis-12, cis-15) by ruminal bacteria (Luna et al., 2008; Fuentes et al., 2006).

According Fuentes et al. (2006), methods employing the $\mathrm{BF}_{3}, \mathrm{HCl}$ or $\mathrm{H}_{2} \mathrm{SO}_{4}$, by increasing the temperature and/or incubation period, favor extensive isomerization of conjugated dienes, reducing the isomer trans-10-cis12 , but increasing the trans-9-trans-trans and 11-trans10-12 and contributing to the formation of artifacts that may interfere with the chromatographic analysis.

Thus, with increasing interest in the cis and trans isomers of conjugated fatty acids, where an accurate determination of the isomers is desired, the basic catalysis, performed at room temperature is considered as the most reliable identification of conjugated fatty acid isomers, such as CLA, isomers, or do not produce artifacts and reduce the loss of short-chain fatty acids (Fuentes et al., 2006; Palmiquist and Jenkins, 2003; Li and Watkins, 2001). 
The reagents commonly used in the transesterification of glycerides by basic catalysis is sodium hydroxide $(\mathrm{NaOH})$ or potassium $(\mathrm{KOH})$ in methanol (Millinsk et al., 2008; Ichihara and Fukubayashi, 2010) and sodium methoxide $\left(\mathrm{NaOCH}_{3}\right)$ in methanol (Millinsk et al., 2008). Transesterification with these reagents can be developed at room temperature in a short period of time. On the other hand, a disadvantage is that they do not convert free fatty acids in FAME, which limit its application to oils with high acidity (Simionato et al., 2010; Ichihara and Fukubayashi, 2010). For the analysis of CLA in samples having high levels of free fatty acids, Kramer et al. (1997) reported a method using acid and base catalysis in sequence. This method resulted in less loss of CLA which catalyzed the methylation only acid, as well as a full methylation of the free fatty acids.

Many studies aimed at evaluating the quality of meat from ruminants have used the method described by ISO (1978) for the transesterification of fatty acids from lipids extracted by cold methods (Fugita et al., 2012; Ito et al., 2012; Zawadzki et al., 2011, Valero et al., 2011, Ito et al., 2010, Sun et al., 2009; Ducatti et al., 2009, Oliveira et al., 2009; Orellana et al., 2009; Polyana et al., 2009; Maggione et al., 2009, Prado et al., 2009a; 2009b, Abrahão et al., 2008, Kazama et al., 2008, Prado et al., 2008a; 2008b; 2008c; 2008d; Macedo et al., 2008; Aricetti et al., 2008), among them, few have worked with the identification of different isomers of CLA (Oliveira et al., 2009; Prado et al., 2009a; 2009b; Aricetti et al., 2008; Prado et al., 2008a). Moreover, Sun et al. (2009), did methylation lipids extracted with sodium methoxide in methanol and $\mathrm{HCl}$ in methanol at $80^{\circ} \mathrm{C}$ for 10 minutes, according to the procedure described by Sukhija and Palmiquist (1988) and Kramer et al. (1967) modified to quantify the isomers of CLA in samples of muscle and liver of cattle.

In accordance with $\mathrm{Li}$ and Watkins (2001), there is no single method that works optimally in all situations. The researcher must know the nature of the sample and select the appropriate method.

\section{CONCLUSION}

Through knowledge of the nature of the lipids samples it is possible to choose the best method of lipid extraction and transesterification of FAME. The methods used for analyzing the meat of lipids to ruminants are as described by Bligh and Dyer (1959) to quantify total lipid and the method described by ISO (1978) to the transesterify FA. The advantages of these methods are related to the use of small volumes of reagents, little manipulation and quick analysis and not having to heat the reactants. With the increased interest in conjugated fatty acid isomers, these methodologies are suitable for the analysis of meat does not alter the conformation of the isomers found naturally in ruminant products. However, as observed in literature, variations in methods of extraction of lipids should be thoroughly compared with the original methods so to ensure reliable results.

\section{REFERENCES}

Abrahão, J.J., S. Marques, J.A. Macedo, L.M. Prado and J.M. Visantainer, et al., 2008. Composição química e perfil de ácidos graxos do músculo Longissimus de bovinos de diferentes grupos genéticos terminados em confinamento. Acta. Sci. Anim. Sci., 30: 443-449. DOI: 10.4025/actascianimsci.v30i4.465

Alerstam, T. and D.A. Christie, 1993. Bird Migration. 1st Edn., Cambridge University Press, Cambridge, ISBN-10: 0521448220, pp: 420.

AOAC, 1995. Official Methods of Analysis. 16th. Edn., AOAC, International, Gaithersburg, MD.

Aricetti, J.A., P.P. Rotta, R.M. Prado, D. Perotto and J.L. Moletta, et al., 2008. Carcass characteristics, chemical composition and fatty acid profile of Longissimus muscle of bulls and steers finished in a pasture system bulls and steers finished in pasture systems. Asian Aus. J. Anim. Sci., 21: 1441-1448.

Aued-Pimentel, S., M.M.M. Kus, E.E. Kumagai, V. Ruvieri and O. Zenebonet, 2010. Comparison of gas chromatographic and gravimetric methods for quantization of total fat and fatty acids in foodstuffs. Quim Nova, 33: 76-84. DOI: 10.1590/S010040422010000100015

Bligh, E.G. and W.J. Dyer, 1959. A rapid method of total lipid extraction and purification. Can. J. Bioc. Physiol., 37: 911-917. PMID: 13671378

Bragagnolo, N., 2001. Aspectos comparativos entre carnes Segundo a composição de ácidos graxos e teor de colesterol. Proceeding of the 2nd Internacional Conferencia Virtual sobre Qualidade de Carnes Suína, Nov. 5-6, Concordia, SC, Brasil, pp: 393-402.

Cheng, C.H., T.B. Du, H.C. Pi, S.M. Jang and Y.H. Lin, et al., 2011. Comparative study of lipid extraction from microalgae by organic solvent and supercritical CO2. Bior. Technol., 102: 10151-10153. DOI: 10.1016/j.biortech.2011.08.064

Christie, W.W., 1991. Preparation of lipid extracts from tissue. Lipid Technol., 3: 97-98.

Christie, W.W., 2011. Gas chromatographic analysis of fatty acid methyl esters with high precision. James Hutton Institute.

Ducatti, T., I.N. Prado, P.P. Rotta, R.M. Prado and D. Perotto, et al., 2009. Chemical Composition and Fatty Acid Profile in Crossbred (Bos taurus vs. Bos indicus) Young Bulls Finished in a Feedlot. Asian Aus. J. Anim. Sci., 22: 433-439. 
Eder, K., 1995. Gas chromatographic analysis of fatt acid methyl esters. Rev. J. Chrom. B., 671: 113- 131. DOI: $10.1016 / 0378-4347(95) 00142-6$

Fernandes, A.R.M., A.A.M. Sampaio, W. Henrique, R.R. Tullio and E.A. Oliveira, et al., 2009. Composição em ácidos graxos e qualidade da carne de tourinhos Nelore e Canchim alimentados com dietas à base de cana-de-açúcar e dois níveis de concentrado. Braz. J. Anim. Sci., 38: 328-337. DOI: 10.1590/S151635982009000200016

Folch, J., M. Lees and S.G.H. Stanley, 1957. A simple method for the isolation and purification of total lipids from animal tissues. J. Biol. Chem., 226: 497509. PMID: 13428781

Fuentes, M.A., P. Luna and M. Juárez, 2006. Chromatographic techniques to determine conjugated linoleic acid isomers. Trends Anal. Chem., 25: 917-926. DOI: 10.1016/j.trac.2006.04.012

Fugita, C.A., I.N. Prado, C.C. Jobim, F. Zawadzki and M.V. Valero, et al., 2012. Corn silage with and without enzyme-bacteria inoculants on performance, carcass characteristics and meat quality in feedlot finished crossbred bulls. Braz. J. Anim. Sci., 41: 154-163. DOI: 10.1590/S1516-35982012000100023

Grummer, R.R., 1991. Effect of feed on the composition of milk fat. J. Dairy Sci., 74: 3244-3257. PMID: 1779073

Hammond, W.E., 2001. How the past teaches the future: ACMI distinguished lecture. J. Am. Med. Inform. Assoc., 8: 222-234. PMID: 11320067

Ichihara, K. and Y. Fukubayashi, 2010. Preparation of fatty acid methyl esters for gas-liquid chromatography. J. Lipid Res., 51: 635-640. DOI: 10.1194/jlr.D001065

ISO, 1978. International Organization for Standardiztion. ISO.

Ito, R.H., I.N. Prado, J.V. Visentainer, R.M. Prado and C.A. Fugita, et al., 2010. Carcass characteristics, chemical and fatty acid composition of Longissimus muscle of Purnã bulls slaughtered at 18 or 24 months of age. Acta. Sci. Anim. Sci., 32: 299-307. DOI: $10.4025 /$ actascianimsci.v32i3.7274

Ito, R.H., I.N. Prado, P.P. Rotta, M.G. Oliveira and R.M. Prado, et al., 2012. Carcass characteristics, chemical composition and fatty acid profile of longissimus muscle of yong bulls from four genetic groups finished in feedlot. Braz. J. Anim. Sci., 41: 384391.DOI: 10.1590/S1516-35982012000200022

Jorge, J.R.V., L.M. Zeoula, I.N. Prado, R.R. Silva and R.V. Andrade, et al., 2009. Gordura protegida sobre o desempenho, carcaça e composição química da carne de novilhos Holandês. Arch Zootec., 58: 371-382.

Kazama, R., L.M. Zeoula, I.N. Prado, D.C. Silva and T. Ducatti, et al., 2008. Características quantitativas e qualitativas da carcaça de novilhas alimentadas com diferentes fontes energéticas em dietas à base de cascas de algodão e soja. Braz. J. Anim. Sci., 37: 350-357. DOI: 10.1590/S1516-35982008000200023
Kramer, J.C., V.S. Fischman and D.C. Littlefield, 1967. Author amphetamine abusepattern and effects of high doses taken intravenously affiliations. J. Am. Med. $\quad$ Associ., 201: 305-309. DOI:10.1001/jama.1967.03130050039011

Kramer, J.K.G., V. Fellner, M.E.R. Dugan, F.D. Sauer and M.M. Mossoba, et al., 1997. Evaluating acid and base catalysts in the methylation of milk and rumen fatty acids with special emphasis on conjugated dienes and total trans fatty acids. Lipids, 32: 1219-1228. DOI: 10.1007/s1 1745-997-0156-3

Kuss, F., J. Restle, G.V. Kosloski, A.P. Santos and L.F.G. Menezes, et al., 2006. Perfil de ácidos graxos da gordura intramuscular da carne de vacas de descarte de diferentes grupos genéticos terminadas em confinamento, abatidas com distintos pesos. Cienc. Rural, 37: 815-820. DOI.org/10.1590/S010384782006000500027

Li, Y. and B.A. Watkins, 2001. Analysis of fatty acids in food lipids. John Wiley and Sons, Inc.

Luna, P., M. Juárez and M.A. Fuente, 2008. Gas chromatography and silve-ion high-performance liquid chromatography analysis of conjugated linoleic acid isomers in free fatty acids using sulphuric acid in methanol as catalyst. J. Chrom. A, 1204: 110-113. DOI: 10.1016/j.chroma.2008.07.050

Macedo, L.M.A., I.M. Prado, J.M. Prado, P.P. Rotta and R.M. Prado, et al., 2008. Chemical composition and fatty acids profile of five carcass cuts of crossbred heifers finished in feedlot, Semina: Ci. Agric., 29: 597-608.

Maggione, D., J.A. Marques, P.P. Rotta, D. Perotto and T. Ducatti et al., 2009. Animal performance and meat quality of crossbred young bulls. Livestock Sci., 127: 176-182. DOI: 10.1016/j.livsci.2009.09.006

Manirakiza, P., A. Covaci and P. Schepens, 2001. comparative study on total lipid determination using soxhlet, roese-gottlieb, bligh dyer and modified bligh dyer extraction methods. J. Food Comp. Anal., 14: 93-100. DOI: $10.1006 /$ jfca.2000.0972

Millinsk, M.C., M. Matsushita, J.V. Visentainer, C.C. Oliveira and N.E. de Souza, 2008. Comparative analysis of eight esterification methods in the quantitative determination of vegetable oil Fatty Acid Methyl Esters (FAME). J. Braz. Chem. Soci., 19: 1475-1483. DOI: 10.1590/S010350532008000800006

Millinsk, M.C., M. Matsushita, J.V. Visentainer, L.F. Dias and M.M. Yamaguchi, et al., 2011. Influence of the esterefication method on the quantification of olive oil fatty acids. Semina. Exact Technol. Sci., 32: $139-150 . \quad$ DOI: $10.5433 / 1679$ $0375.2011 \mathrm{v} 32 \mathrm{n} 2 \mathrm{p} 139$

Morrison, W.R. and L.M. Schmidt, 1964. Preparation of fatty acid methyl esters and dimethylacetals from lipids with boron fluoride-methanol. J. Lipid Res., 5: 600-608. 
Oliveira, A.N., R.M. Prado, C.A. Fugita, P.P. Rotta and N.E. de Souza, 2009. Chemical composition, fatty acid profile and CLA levels in the Longissimus muscle of Caracu and Caracu vs Charolais cattle. Semina: Ciênc. Agr., 30: 727-236.

Orellana, C., F. Peña, B. Garcia, J. Perea and J. Martos, et al., 2009. Carcass characteristics, fatty acid composition and meat quality of Criollo Argentino and Braford steers raised on forage in semi-tropical region of Argentina. Meat Sci., 81: 57-64. DOI: 10.1016/j.meatsci.2008.06.015

Palmiquist, D.L. and T.C. Jenkins, 2003. Challenges with fats and fatty acid methods. J. Anim. Sci., 81: 3250-3254.

Polyana, P.R., N.D.P. Ivanor, D.P.R. Martin, L. M. José and R.S. Robério et al., 2009. Carcass characteristics and chemical composition of the Longissimus muscle of Nellore, Caracu and Holstein-friesian bulls finished in a feedlot. AsianAust. J. Anim. Sci., 22: 598-604.

Prado, I.N., J.A. Aricetti, P.P. Rotta, R.M. Prado and D. Perotto, et al., 2008a. Carcass characteristics, chemical composition and fatty acid profile of the longissimus muscle of bulls (bos taurus indicus vs. bos taurus taurus) finished in pasture systems. Asian-Aust. J. Anim. Sci., 21: 1449-1457.

Prado, I.N., R.H. Ito, J.M. Prado, I.M. Prado and P.P. Rotta, 2008b. The influence of dietary soybean and linseed on the chemical composition and fatty acid profile of the Longissimus muscle of feedlotfinished bulls. J. Anim. Feed Sci., 17: 307-317.

Prado, I.N., R.M. Prado, P.P. Rotta, J.V. Visantainer and J.L. Moletta, et al., 2008c. Carcass characteristics and chemical composition of the Longissimus muscle of crossbred bulls (Bos Taurus indicus vs Bos taurus taurus) finished in feedlot. J. Anim. Feed Sci., 17: 295-306.

Prado, I.N.D., P.P. Rotta, R.M. Do Prado, J.V. Visantainer and J.L. Moletta, et al., 2008d. Carcass characteristics and chemical composition of the Longissimus muscle of Puruna and 1/2 Puruna vs. $1 / 2$ Canchin bulls meat quality of bulls. Asian-Aust. J. Anim. Sci.,

Prado, I.N.D., A.N.D. Oliveira, P.P. Rotta, D. Perotto and R.M. Prado, 2009a. Chemical and fatty acid composition of longissimus muscle of crossbred bulls finished in feedlot. Asian-Aust. J. Anim. Sci., 22: 1054-1059.

Prado, I.N., J.A. Marques, P.P. Rotta, R.M. Prado and J.V. Visentainer, et al., 2009b. Meat qualityof the Longissimus muscle of bulls and steers $(1 / 2$ Nellore vs. $1 / 2$ Simental) finished in feedlot. J. Anim. Feed Sci., 18: 221-230.

Rossato, L.V., M.C. Bressan, E.C. Rodrigues, M.I.A.C.M. Carolino and R.J.B. Bessa, et al., 2009. Composição lipídica de carne bovina de grupos genéticos taurinos e zebuínos terminados em confinamento. Braz. J. Anim. Sci., 38: 1841-1846. DOI: $10.1590 / \mathrm{S} 1516-35982009000900029$
Ruiz, M.R., M. Matsushita, J.V. Visentainer, J.A. Hernandez and L.A. Ribeiro, et al., 2005. Proximate chemical composition and fatty acid profiles of Longissimus thoracis from pasture fed LHRH immunocastrated, castrated and intact Bos indicus bulls. South African J. Anim. Sci., 35: 13-18.

Sahidi, F., 2001. Extraction and Measurement of total lipids. Lipid Comosition Current Protocols in Food Analytical Chemistry.

Silva, R.G., I.N. Prado, M. Matsushita and N.E. de Souza, 2002. Dietary effects on muscle fatty acid composition of finished heifers. Pesq. Agropec. Bras., 37: 95-101. DOI: 10.1590/S0100204X2002000100013

Simionato, J.I., J.C. Garcia, G.T. Santos, C.C. Oliveira and J.V. Visentainer, et al., 2010. Validation of the determination of fatty acids in milk by gas chromatography. J. Braz. Chem. Soc., 21: 520-524, DOI: $10.1590 / \mathrm{S} 0103-50532010000300018$

Stark, J.M. and M.K. Firestone, 1996. Kinetic characteristics of ammonium-oxidizer communities in a California oak woodland-annual grassland. Soil Biology and Biochemistry, 28: 1307-1317. DOI: 10.1016/S0038-0717(96)00133-2

Sukhija, P.S. and D.L. Palmiquist, 1988. Rapid method for determination of total fatty acid content and composition of feedstuffs and feces. J. Agric. Food Chem., 36: 1202-1206. DOI: 10.1021/jf00084a019

Sun, W., G.Y. Zhao, E.L. Song, F.C. Wan and X.M. Liu, et al., 2009. The effect of feeding soyabeans with different particle size on the content of conjugated linoleic acid and other fatty acids of longissimus dorsi muscle, backfat and liver of beef cattle. J. Anim. Feed Sci., 18: 388-398.

Tanamati, A., C.C. Oliveira, J.V. Visentainer, M. Matsushita and N. E. deSouza, 2005. Comparative study of total lipids in beef using chlorinated solvent and low-toxicity solvent methods. J. Am. Oil Chem. Soc., 82: 393-397. DOI: 10.1007/s11746-005-1083-4

Valero, M.V., F. Zawadzki, M.C. Françozo, M.S. Faria and P.P. Rotta, et al., 2011. Sodium monensin or própolis extract in diet of crossbred $(1 / 2$ Red Angus vs. $1 / 2$ Nellore) bulls finished in feedlot: chemical composition and fatty acid profile of the Longissimus muscle. Semina: Ciênc. Agr., 32: 1617-1626. DOI: 10.5433/16790359.2011v32n4p1617

Whetsell, M.S., E.B. Rayburn and E.J.D. Lozier, 2003. Human health effects of fatty acids in beef. Extension Service-West Virginia University, U.S. Department of Agriculture Res. Ser. Virginia Technol.

Zawadzki, F., I.N. Prado, J.A. Marques, L.M. Zeoula and R.M. Prado, et al., 2011. Sodium monensin or propolis extract in the diet of nellore bulls finished in feedlot: Chemical composition and fatty acid profile of longissimus muscle. Semina: Ciênc. Agr., 32: $1627-1636$. DOI: $10.5433 / 1679$ $0359.2011 \mathrm{v} 32 \mathrm{n} 4 \mathrm{p} 1627$ 